Biografistyka Pedagogiczna

Year 5 (2020) No. 2

ISSN 2543-6112; e-ISSN 2543-7399

DOI: $10.36578 /$ BP.2020.05.13

\title{
Agnieszka Gołda*
}

\section{Didactic activities of Stefan Vrtel-Wierczyński at the University of Poznan during the Second Polish Republic}

\section{Działalność dydaktyczna Stefana Vrtela-Wierczyńskiego na Uniwersytecie Poznańskim w II Rzeczypospolitej}

\begin{abstract}
This article describes the didactic activities of Stefan Vrtel-Wierczyński, a lecturer in the Faculty of Humanities at the University of Poznań. Between 1928 and 1937, the director of the University Library also gave classes in the history of Polish literature, bibliography, bibliology and librarianship, supporting the seminar of the history of Polish literature by Tadeusz Grabowski, Stanisław Dobrzycki and Roman Pollak. The content of his classes is characterised and the most important elements of their organisation are indicated.
\end{abstract}

Keywords: The Second Polish Republic, teaching, humanities, academic education, the University of Poznań, Stefan Vrtel-Wierczyński.

Abstrakt: Przedstawiono działalność dydaktyczną Stefana Vrtela-Wierczyńskiego - wykładowcy Wydziału Humanistycznego Uniwersytetu Poznańskiego. W latach 1928-1937 dyrektor Biblioteki Uniwersyteckiej podjął dodatkowo zajęcia z zakresu dziejów literatury polskiej, bibliografii, bibliologii i bibliotekarstwa, wspomagając seminarium historii literatury polskiej Tadeusza Grabowskiego, Stanisława Dobrzyckiego i Romana Pollaka. Scharakteryzowano treści zajęć oraz wskazano najważniejsze elementy ich organizacji.

* Agnieszka Gołda, drhab (ORCID: 0000-0001-6571-5304) - a professor of the University of Silesia, works at the Institute of Cultural Sciences at the University of Silesia in Katowice, contact: agnieszka.golda@us.edu.pl 
Słowa kluczowe: II Rzeczypospolita, dydaktyka, humanistyka, kształcenie akademickie, Uniwersytet Poznański, Vrtel-Wierczyński Stefan.

\section{Introduction}

0 n 1 September 1927, Stefan Vrtel-Wierczyński (1886-1963), a bibliologist, philologist and editor, took up the position of the director of the library of the University of Poznan. ${ }^{1}$ The new employee combined his professional duties with research devoted to the science of books, with particular emphasis on bibliography. As a result of his activity, he received habilitation (a post-doctoral degree) in the field of auxiliary sciences - bibliography and librarianship in Lviv in 1923, which was extended in 1927 to include the history of Polish literature and its relations with Czech literature. After starting work as library director, from 20 March 1928 he also continued his habilitation studies in Poznań. ${ }^{2}$ This allowed him to start teaching. On 4 April 1936, he became the titular professor of bibliology and bibliography at the University of Poznań. ${ }^{3}$ He stayed in the Wielkopolska region until 1937, when, according to a letter from the Minister of Religious Denominations and Public Education of 1 July 1937 no. 15341/37, he accepted the post of director of the National Library in Warsaw. ${ }^{4}$

Academic teaching was among Vrtel-Wierczyński's achievements, in addition to librarianship. ${ }^{5}$ It was thanks to his efforts that the university curriculum

1 J. Koller, 'Nowy dyrektor Biblioteki Narodowej w Warszawie', Monitor Polski, 149 (1937) p. 9.

2 [Inc.: Rok akademicki 1928/29], Kronika Uniwersytetu Poznańskiego za rok szkolny 1927/28, 1928, p. 8; J. Maciejewski, Dzieje poznańskiej polonistyki uniwersyteckiej 18421988, Poznań 1992, p. 48.

3 'Wydział Humanistyczny', Kronika Uniwersytetu Poznańskiego za rok szkolny 1935/36, 1937, p. 107; J. Koller, Nowy dyrektor Biblioteki Narodowej, p. 9; J. Maciejewski, Dzieje poznańskiej polonistyki, p. 48.

4 'Biblioteka Uniwersytecka. Sprawozdanie dyrektora Biblioteki Uniwersyteckiej prof. dra S. Wierczyńskiego za rok akademicki 1936/37', Kronika Uniwersytetu Poznańskiego za rok szkolny 1936/37, 1938, p. 81.

5 He reorganised the library (e.g. opened a reading room for periodicals and an interlibrary lending room) and took care of the planned collection of resources (a foreign literature exchange section and a legal deposit section, thanks to which it was possible to Polonise the book collection, as initiated by Edward Kuntze). On his initia- 
offered students classes that covered the problems of book culture in a broad sense. The content and organisation of these classes are the subject of this study.

At this point, the uniqueness of the scope of the lectures and exercises undertaken by Vrtel-Wierczyński should be emphasised. During these, he discussed the history of Polish literature, which was the result of his studies at the Jan Kazimierz University in Lviv, ${ }^{6}$ and also the science of books, which was extremely rare within universities at that time. This subject appeared in educational centres in the territory of the Republic of Poland at the beginning of the 19th century. ${ }^{7}$ At that time, departments of the science of books, called bibliology, and more often bibliography, were established. They were launched in Krzemieniec, Cracow, Vilnius and Warsaw. ${ }^{8}$ The situation changed

tive, work was undertaken on the catalogue of university seminar and department libraries, the central catalogue of magazines and serial publications in Poznań libraries, and the central catalogue of foreign magazines from Polish scientific libraries. VrtelWierczyński also inaugurated the activities of the Society of Friends of the University Library in 1929. Thanks to him, the 'Biuletyn Biblioteczny' [Library Bulletin] was created and reports on the activities of the library began to be published. B. Świderski, 'Stefan Vrtel-Wierczyński 1886-1963', Roczniki Biblioteczne, 1-2 (1963) pp. 11-12; A. Puciatowa, 'Wspomnienie o dyrektorze Biblioteki Narodowej Stefanie Wierczyńskim', Rocznik Biblioteki Narodowej, 17-18 (1981-1982) p. 425; Z. Szkutnik, 'Stefan VrtelWierczyński jako bibliotekarz', Roczniki Biblioteczne, 1-2 (1984) pp. 18-29.

6 From 1905 to 1909, he studied Polish, Slavic and classical philology as well as bibliography. K. Tokarzówna, 'Stefan Vrtel-Wierczyński (26 grudnia 1886 - 3 lutego 1963)', Pamiętnik Literacki, 4 (1963) p. 557.

7 Cf. e.g. J.Włodarczyk, 'Bibliotekarze bibliotek fundacyjnych i rodowych w okresie zaborów - próba syntezy. Z dziejów kształtowania się zawodu bibliotekarskiego na ziemiach polskich', Roczniki Biblioteczne, 1-2 (1984) pp. 179-195.

8 The classes were run by: Paweł Jarkowski, Jerzy Samuel Bandtkie, Jan Kanty Rzesiński, Józef Muczkowski, Aleksander Bohatkiewicz, Joachim Lelewel and Karol Estreicher. For example, J. Korpała, Dzieje bibliografii w Polsce, Warszawa 1969; K. Warda, 'Paweł Jarkowski - bibliotekarz i bibliograf', Kieleckie Studia Bibliologiczne, 2 (1995) pp. 9-29; Z. Ciechanowska, 'Jerzy Samuel Bandtkie jako bibliotekarz i bibliotekoznawca', Biuletyn Biblioteki Jagiellońskiej, 1-2 (1970) pp. 5-23; K. Lewicki, 'Jerzy Samuel Bandtkie profesor bibliografii Uniwersytetu Jagiellońskiego 1811-1835', Roczniki Biblioteczne, 1-2 (1972) pp. 113-138; W. Nowodworski, „Bibliograficznych ksiag dwoje” Joachima Lelewela. Studium historyczno-bibliograficzne na tle epoki, Wrocław 1959; I. Treichel, 'Pierwszy polski podręcznik bibliotekarski', Roczniki Biblioteczne, 1-2 (1957) pp. 167-230; M. Kłossowska, 'Aleksander Wiktor Bohatkiewicz. (Pierwszy wileński teoretyk i wykładowca bibliografii)', Studia o Ksiażce, 2 (1971) pp. 221-239; M. M. Biernacka, Wykłady Karola Estreichera w Szkole Głównej w Warszawie 1865-1868. Studium bibliologiczne, Warszawa 1989. 
in the second half of the 19th century, when the aforementioned centres were closed, and the elements of the science of books could only be learned during courses for library workers, particularly after Poland regained independence. ${ }^{9}$

In the interwar period:

The question of introducing library science into university curricula was not...simple. As a scientific discipline, it was not yet crystallised, as a practical skill, it met with some resistance from the academic world, guarding disciplines sanctified by centuries-old tradition. It also did not have a specific professional goal because the legislation of that time did not provide for a separate librarian profession with specific rights and obligations..$^{10}$

Nevertheless, outstanding historians of literature and books conducted lectures covering elements of knowledge about books in Cracow (Aleksander Birkenmajer), Lublin (Stanisław Ptaszycki, Wiktor Hahn), Lviv (Eustachy Gaberle, Wiktor Hahn, Eugeniusz Kucharski, Hilarion Święcicki), Warsaw (Tadeusz Sterzyński) and Vilnius (Erwin Koschmieder, Adam Łysakowski). However, there were no permanent departments of bibliology/bibliography at state universities, ${ }^{11}$ despite the appeals of the rectors of the Stefan Batory University in Vilnius, Aleksander Januszkiewicz (1930-1932) and Alfons Parczewski (19221924) at the convention of librarians in $1932{ }^{12}$

The University of Poznan was closest to the creation of an appropriate department, where Vrtel-Wierczyński held the position of associate professor. He followed the principle:

9 L. Bykowski, 'Biblioteczna praca informacyjna w Polsce', Wiedza i Życie, 5 (1934) p. 436.

10 H. Więckowska, Akademickie kształcenie bibliotekarzy. Zarys historyczny, Warszawa 1979, p. 24.

11 In the interwar period, classes in librarianship could only be studied at a private university, namely at the Free Polish University in Warsaw (1925-1939), which did not have the right to award academic degrees. A. Gołda, Teoria bibliografii w II Rzeczypospolitej, Katowice 2018, pp. 165-167.

$12 W$ sprawie studium bibliografii i bibliologii, in: Zespół akt prof. S. Wierczyńskiego. Archiwum Oddziału Polskiej Akademii Nauk w Poznaniu, ref. no. P. III - 32. Katedra bibliologii - 1936, entry no. 139. 
Due to the great scientific importance of bibliography, bibliology and librarianship, it is necessary to provide these skills with a proper position in the organisation of university studies and in the secondary school curriculum (in secondary schools). ${ }^{13}$

\section{The science of books at Piast University and the University of Poznan between 1919 and 1921}

Before Vrtel-Wierczyński arrived in Poznań, Edward Kuntze, the director of the University Library from 1919 to $1926,{ }^{14}$ conducted a specialist course for librarians from 1 November 1919 to 16 July $1920 .{ }^{15}$ According to Marian Łodyński, it was the first in the free Republic of Poland to be 'filled with his [Kuntze - the author's note] lectures forthe lion's share. ${ }^{16}$ The University Library Board was the main organiser of the course. It was dedicated to librarians with secondary education, and it gave the opportunity to gain theoretical preparation in the field of librarianship and practical familiarisation with professional duties. ${ }^{17}$

The programme of the course was based on the plans of the Jagiellonian Library in Cracow approved by the Ministry of Religious Denominations and Public Education. ${ }^{18}$ Every two months, students were assigned to successive library departments, and Kuntze himself gave daily lectures on bibliography (two hours), bibliology (one hour), the history of libraries (one hour) and library

13 Ibid.

14 Cf. J. Baumgart, 'Działalność Edwarda Kuntzego na stanowisku dyrektora Biblioteki Uniwersyteckiej w Poznaniu (1919-1926)', Przegląd Biblioteczny, 2/3 (1957) pp. 106-111.

15 The problem in the newly created Library was the library staff. When Kuntze became the director, only one person had professional qualifications and was responsible for compiling the collections, while another (from the German staff) worked in a technical position; J. Baumgart, Działalność Edwarda Kuntzego, p. 108.

16 M. Łodyński, 'Rola Edwarda Kuntzego w bibliotekarstwie polskim', Przegląd Biblioteczny, 2-3 (1957) p. 100.

17 'Kurs bibliotekarski w Poznaniu', Bibliotekarz, 5/6 (1919) pp. 78-79; 'Kurs dla kandydatów na bibliotekarzy o średnim wykształceniu dla bibliotek naukowych w Bibliotece Uniwersyteckiej w Poznaniu', Exlibris, 3 (1920) pp. 80-82.

18 S. Vrtel-Wierczyński, Biblioteka Uniwersytecka 1919-1929, in: Biblioteki wielkopolskie i pomorskie, (ed.) S. Wierczyński, Poznań 1929, p. 105. 
technology (one hour). In addition to this, one hour was devoted to alphabetical cataloguing and practical exercises. Bożena Szulc-Golska, a translator and librarian, took care of these classes. Additionally, for three hours each week, the participants learned Latin and had to master their typing skills. ${ }^{19}$ Thus, the curriculum enabled professional preparation for work in a library.

Military action prevented the completion of the second cycle of the course, which was intended for already trained scientific librarians. It took place from 11 January to 9 May 1921 and finally came to an end when Kuntze was appointed to the Mixed Delegation of the Polish-Soviet Special Commission in Moscow in $1923 .{ }^{20}$

In this edition, the course was modified - it took the form of philological and academic training, preparing participants for independent scientific research. Therefore, among the subjects taught, there were issues related to the classification of sciences, the history of writing, woodcut and copperplate engraving, books and libraries, the history of comparative linguistics and legal sciences, Slavic, classical, Polish, Roman and Germanic literature, historiography, economics and philosophy. Professional classes were only represented by the theory and the outline of the history of bibliography, and in the training element, students could learn about works covering the problems of the theory of bibliography. Students also prepared speeches. ${ }^{21}$

The notes from these courses later helped those who worked in this area, including Jan Baumgart, who assessed Kuntze's contribution to bibliological and philological didactics as follows:

Director Kuntze made an outstanding contribution to training. He brought up a whole generation of librarians, created a kind of school of Polish librarianship, all the more valuable as it was the first training course conducted in Poland. All employees, both those who had the opportunity to listen to these

19 J. Baumgart, Działalność Edwarda Kuntzego, p. 109.

20 B. Góra, „Poznańczycy”: Edward Kuntze, Stefan Vrtel-Wierczyński, Aleksander Birkenmajer $i$ ich reformatorska polityka biblioteczna, in: Oblicza współczesnej bibliologii. Konteksty i transgresje, (eds) G. Czapnik, Z. Gruszka, J. Ladorucki, Łódź, Warszawa 2014, p. 420.

21 'Z Uniwersytetu Poznańskiego', Dziennik Poznański, 148 (1920) p. 2; S. VrtelWierczyński, Biblioteka Uniwersytecka 1919-1929, p. 106. 
lectures and those who used the notes, remember this side of Director Kuntze's activity with gratitude. ${ }^{22}$

\section{Stefan Vrtel-Wierczyński as a lecturer at the University of Poznań}

Once again, the science of books appeared at the University of Poznan thanks to Vrtel-Wierczyński, who became a lecturer in the Faculty of Humanities, which evolved from the Faculty of Philosophy established in 1919. The Faculty consisted of 21 departments, including 13 in Humanities and eight in Mathematics and Natural Sciences. Outstanding professors ${ }^{23}$ and associate professors ${ }^{24}$ worked there. The unit functioned in this format until 1925, when it was divided into the Faculty of Humanities and the Faculty of Mathematics and Natural Sciences. ${ }^{25}$

22 J. Baumgart, Działalność Edwarda Kuntzego, p. 110.

23 Theywere, among others: Jan Stanisław Bystron (ethnographer and sociologist), Antoni Danysz (historian of culture and education), Alfred Denizot (physicist), Stanisław Dobrzycki (literary historian), Ryszard Ganszyniec (cultural historian), Tadeusz Grabowski (literary historian), Jan Grochmalicki (zoologist), Seweryn Hammer (classical philologist), Antoni Korczyński (chemist), Józef Kostrzewski (archaeologist and museologist), Zdzisław Krygowski (mathematician and cryptologist), Tadeusz Lehr-Spławiński (linguist and Slavist), Bronisław Niklewski (plant physiologist), Stanisław Pawłowski (geographer), Eugeniusz Piasecki (physical education theorist), Mikołaj Rudnicki (linguist), Jan Sajdak (classical philologist and Byzantine specialist), Michał Sobeski (historian of philosophy), Kazimierz Tymieniecki (historian-medievalist), Stanisław Wędkiewicz (literary historian and linguist) and Franciszek Włodarski (mathematician).

24 Among others, Stefan Błachowski (psychologist), Ludwika Dobrzyńska-Rybicka (philosopher), Fr Szczęsny Dettloff (art historian), Fr Wacław Gieburowski (musicologist), Władysław Kudelka (botanist), Stanisław Pigoń and Roman Pollak (historians of Polish literature).

25 A. Kobelska, Miasto. Uniwersytet. Literaturoznawstwo. Poznań lat dwudziestych i trzydziestych XX wieku jako przestrzeń działania członków Koła Polonistów, Warszawa 2016, p. 56. Cf. Wydziat Filozoficzny, in: Uniwersytet Poznański w pierwszych latach swego istnienia (1919, 1919-20, 1920-21, 1921-22, 1922-23) za rektoratu Heliodora Święcickiego. Księga pamiątkowa wydana staraniem Senatu Uniwersytetu Poznańskiego, (ed.) A. Wrzosek, Poznań 1924, pp. 357-583; (s.b.), 'Podział Wydziału filozoficznego Uniwersytetu Poznańskiego', Kurier Poznański, 313 (evening edition) (1925) p. 7; J. Maciejewski, Dzieje poznańskiej polonistyki; G. Łukomski, Jak powstał Uniwersytet Poznański, in: W Trzemesznie i nie tylko... Obchody 85-lecia Uniwersytetu im. Adama Mickiewicza, (ed.) B. Walczak, Poznań 2006, pp. 110-111. 
When Vrtel-Wierczyński began working at the university, the Faculty of Humanities offered the possibility of studying many areas of knowledge, including philosophy, psychology, pedagogy, sociology, ethnology, prehistory, anthropology, history and auxiliary sciences, classical archaeology, art history, musicology, comparative linguistics and the languages of the Ancient East, classical philology, modern philology, and the history of newer literatures. Many structural changes took place in the Faculty in the 1933/1934 academic year, following the Act of 11 March 1932 on the education system and soon after the Act of 15 March 1933 on academic schools, that is, Jędrzejewicz's reform, entered into force. ${ }^{26}$ The Ministry of Religious Denominations and Public Education then decided to close six Poznan departments, including those of the history of Polish literature, general history, oriental studies, classical philology and the history of philosophy and pedagogy. Four professors were also dismissed, which weakened the staff of the Faculty. ${ }^{27}$

When new legal regulations were introduced at the university in June 1933, Vrtel-Wierczyński made intensive efforts on behalf of the Committee of Higher School Libraries of the Polish Librarians' Union to establish a programme in the field of bibliology and bibliography at universities. He sent a memorandum to the Ministry of Religious Denominations and Public Education and university senates explaining the need to establish appropriate departments. Before they were created, it was necessary to consider ways of organising and introducing commissioned lectures and exercises in bibliology into study programmes. ${ }^{28}$ On 6 February 1934, the Council of the Faculty of Humanities applied to the ministry for the establishment of a bibliography and bibliology department for Vrtel-Wierczyński (efforts were also made for a department of Western Slavic history), arguing the matter as follows:

26 'Since Jędrzejewicz's reform entered into force, it has been widely regarded as an attack by the Sanacja regime on the freedom of science and an attempt to paralyse the prestigious and opinion-forming milieu supporting the anti-government opposition.'J. Jastrzębski, 'Reforma szkolnictwa akademickiego z 1933 roku. Zmiany w organizacji uczelni', Wschodni Rocznik Humanistyczny, 7 (2010-2011) p. 255.

27 'Sprawozdanie dziekana Wydziału Humanistycznego prof. K. Chodynickiego za r. ak. 1933/34', Kronika Uniwersytetu Poznańskiego za rok szkolny 1933/34, 1935, pp. 66-67.

28 W sprawie studium bibliografii i bibliologii, entry no. 139; Z. Szkutnik, Stefan VrtelWierczyński jako bibliotekarz, p. 28. 
The creation of this department will not burden the budget of the ministry because the department is to be subsidised from the salary of the director of the University Library, so that Professor Wierczyński, having remained a professor of bibliology and bibliography, will continue to perform the duties of the director of the University Library, as is often the case at foreign universities, such as the universities of Göttingen and Leipzig. ${ }^{29}$

The ministry, however, did not agree to the establishment of a separate department and Vrtel-Wierczyński, in 1936, made fruitless efforts to establish it, meeting the Minister of Religious Denominations and Public Education (16 October 1936). ${ }^{30}$ Nevertheless, the director of the library introduced a number of subjects in the auxiliary sciences of the history of literature to the study programme.

\section{Stefan Vrtel-Wierczyński's classes in the Faculty of Humanities}

When Vrtel-Wierczyński started working in Poznań, he already had some didactic experience. On 1 September 1909, he started working as a teacher of Polish, Latin and Greek at the Third Secondary School in Lviv. He completed his school duties on 31 October $1918 .{ }^{31}$ In the 1924/1925-1926/1927 academic years, he lectured students of Slavic and Polish studies in the field of auxiliary sciences (bibliography and library science) at the Jan Kazimierz University in Lviv. ${ }^{32}$

29 Konspekt najważniejszych spraw Wydziału Humanistycznego przedstawionych Panu Ministrowi W. R. i O. P. na posiedzeniu Senatu Akademickiego z dn. 9.VI.1936 r. przez Dziekana Wydziału Humanistycznego, in: Zespół akt prof. S. Wierczyńskiego. Archiwum Oddziału Polskiej Akademii Nauk w Poznaniu, sign. P. III - 32. Katedra bibliologii - 1936, entry no. 139; J. Maciejewski, Dzieje poznańskiej polonistyki, p. 48.

30 [List Stefana Wierczyńskiego do Wielce Szanownego Pana Ministra z 26 października 1936 roku], in: Zespół akt prof. S. Wierczyńskiego. Archiwum Oddziału Polskiej Akademii Nauk w Poznaniu, sign. P. III - 32. Katedra bibliologii - 1936, entry no. 139.

31 M. Błochowiak, 'Działalność pedagogiczna i edytorska prof. Stefana VrtelaWierczyńskiego', Roczniki Biblioteczne, 1-2 (1984) p. 75. The result of lectures on bibliography conducted by Vrtel-Wierczyński from 1924 at universities in Lviv, Poznań and Warsaw was his Teoria bibliografii $w$ zarysie [The Outline Theory of Bibliography], written during the occupation from 1941 to 1944 and published in Wrocław after World War II in 1951.

32 In both Lviv and later in Poznań, he engaged students to collect materials for the bibliography of the contents of literary magazines. He also gained the support 
Vrtel-Wierczyński ran his first classes at the Faculty of Humanities in Poznan in the 1928/1929 academic year. ${ }^{33}$ These were part of the seminar on the history of Polish literature, whose directors, from when the University was established, were Tadeusz Grabowski (historian of Polish literature, dean of the Faculty of Humanities in 1922/1923), Stanisław Dobrzycki (historian of literature and a Slavic scholar, rector of the University of Poznan in 1924/1925) 34 $^{34}$ and later also Roman Pollak (historian of Polish literature). Within the seminar, the classes were divided into pro-seminars for beginners and seminars for more advanced learners. Initially, the pro-seminars preparing students for independent work were conducted by Pollak and Stanisław Pigon, and the seminars by Grabowski and Dobrzycki. ${ }^{35}$ The subject of these classes was the interpretation of literary classics, including works by Jan Kochanowski, Mikołaj of Wilkowiecko, Piotr Baryka, Ignacy Krasicki, Franciszek Dmochowski, Zygmunt Krasiński and Adam Mickiewicz. On this basis, the features of the work of individual writers and poets were determined. During seminars and pro-seminars, the works were analysed, interpreted and their links with

of other academic centres in Krakow, Lviv and Vilnius, and professors of these universities: Stanisław Pigoń, Eugeniusz Kucharski and Manfred Kridl. However, the work - coordinated according to Vrtel-Wierczyński's instructions - did not bring the expected results. Cf. W sprawie studium bibliografii i bibliologii, entry no. 139; B. Świderski, Stefan Vrtel-Wierczyński 1886-1963, p. 11; J. Baumgart, 'Działalność prof. Stefana Vrtela-Wierczyńskiego w zakresie bibliografii', Roczniki Biblioteczne, 1-2 (1984) p. 46; J. Starnawski, Ludzie książki. Seria II. Łódź 2008, p. 74; M. Ambros, 'Stefan Vrtel-Wierczyński jako bibliograf', Przegląd Biblioteczny, 1-2 (1964) p. 5.

33 In Kronika Uniwersytetu Poznańskiego za rok szkolny 1928/1929, there is no information about the classes conducted.

34 Vrtel-Wierczyński strengthened Polish studies in Poznań, which was of particular importance after Dobrzycki's death in 1931. Cf. Referat o działalności naukowej Doc. Dra Stefana Wierczyńskiego, in: Zespół akt prof. S. Wierczyńskiego. Archiwum Oddziału Polskiej Akademii Nauk w Poznaniu, sign. P. III - 32. Katedra bibliologii 1936, entry no. 139. Cf. też Filologia nowożytna i historia nowszych literatur, in: Spis wykładów na 1, 2, 3 trymestr roku akademickiego 1931/32, Poznań 1931, pp. 65-66; J. Maciejewski, Dzieje poznańskiej polonistyki, p. 43.

35 'Wydział Humanistyczny', Kronika Uniwersytetu Poznańskiego za rok szkolny 1927/28, 1928, pp. 56-57. 
cultural trends were shown. From the 1929/1930 academic year, the library director collaborated with Pollak's seminar. ${ }^{36}$

Among the classes conducted by Vrtel-Wierczyński, four blocks can be distinguished, three of which were related to the science of books (bibliography, bibliology, librarianship), and the last one to the history of Polish literature.

The bibliographic classes were run for the longest period of time. Over the years, the name changed: An introduction to bibliography with particular emphasis on Polish bibliography (1928/1929); An outline of bibliography with particular emphasis on Polish bibliography (1929/1930 and 1930/1931); An outline of bibliography with particular emphasis on the needs of Polish philologists (1931/1932); A bibliographic introduction to the study of Polish literature (1932/1933 and 1934/1935); An outline of bibliography (1933/1934 and 1935/1936); and The science of books (An introduction to bibliography) (1936/1937).

They covered the issues of the theory and history of the discipline, its terminology and subject. The lecturer discussed the bibliographic method used by philologists. He characterised the birth of bibliography in antiquity and its subsequent development, as well as in the Polish-Lithuanian Commonwealth. He also reviewed the most important sources and bibliographic aids and other informative publications, with particular emphasis on the works of Karol Estreicher and Ludwik Finkel. During classes, students learned to use 'Przewodnik Bibliograficzny'[Bibliographic Guide],'Urzędowy Wykaz Druków' [Official List of Prints] ${ }^{37}$ and special bibliographies needed by students when writing scientific papers. ${ }^{38}$ The nature of these classes changed somewhat in the 1936/1937 academic year, when Vrtel-Wierczyński was already a titular

36 Filologia nowożytna i historia nowszych literatur, in: Spis wykładów na 1, 2, 3 trymestr roku akademickiego 1929/30, Poznań 1929, pp. 58-59.

37 He even asked the Board of the National Library in Warsaw to send one-sided printed copies of Urzędowy Wykaz Druków [Official List of Prints] for teaching purposes. [List Stefana Wierczyńskiego do Zarządu Biblioteki Narodowej w Warszawie z 6 kwietnia 1932 roku], in: Zespół akt prof. S. Wierczyńskiego. Archiwum Oddziału Polskiej Akademii Nauk w Poznaniu, sygn. P. III - 32, entry no. 46.

38 [S. Wierczyński], 'Wykłady księgoznawstwa w Uniwersytecie Poznańskim', Biuletyn Biblioteki Publicznej m.st. Warszawy, 10-11 (1932/1933) p. 70; M. Błochowiak, Działalność pedagogiczna i edytorska, pp. 75-76. 
professor of bibliography and bibliology. ${ }^{39}$ Then they became a practical part of the issues of the science of books. ${ }^{40}$

During the bibliography classes, from the 1929/1930 academic year, students created a list of magazines, and a year later they took part in exercises in bibliographic heuristics, 'knowledge of sources' and the literary bibliography of Polish periodicals of the 19 th century. ${ }^{41}$ In the following year, they again prepared a 19th-century literary bibliography of periodicals and began to register serial publications issued between 1926 and 1930.42 In 1933, the lecturer decided to compile 'the entire Polish literary bibliography'. ${ }^{43}$ These activities were carried out during all the years Vrtel-Wierczyński was employed in the Faculty of Humanities. ${ }^{44}$ The scholar even selected specific titles of periodicals which, in his opinion, deserved a bibliographic approach: in the 1934/1935 academic year, the bibliographies of the materials from Przyjaciel Ludu [Friend of the People] published between 1834 and 1850 were

39 Wydział Humanistyczny, in: Skład Uniwersytetu i spis wykładów na rok akademicki 1936/37, Poznań 1936, p. 25.

40 Umowa o prace, zawarta w Poznaniu, dnia 15 lutego 1937, in: Zespół akt prof. S. Wierczyńskiego. Archiwum Oddziału Polskiej Akademii Nauk w Poznaniu, sign. P. III - 32. Personal archive, entry no. 11; 'Ćwiczenia bibliograficzne', Kronika Uniwersytetu Poznańskiego za rok szkolny 1935/36, 1937, p. 147; Spis wykładów na rok 1936/37, in: Zespół akt prof. S. Wierczyńskiego. Archiwum Oddziału Polskiej Akademii Nauk w Poznaniu, sign. P. III - 32. Personal archive, entry no. 11.

41 'Wydział Humanistyczny', Kronika Uniwersytetu Poznańskiego za lata szkolne 1929/30 i 1930/31, 1932, pp. 77-78.

42 He became interested in magazines during his internship at the library of the OssolińskiNational Institute in Lviv (1906-1908), where he was assigned to the journal department. It was there that he encountered the problem of working with this type of collection. He worked under the supervision of two eminent Ossolinnski bibliographers - Bronisław Czarnik and Ludwik Bernacki. 'Wydział Humanistyczny', Kronika Uniwersytetu Poznańskiego za rok szkolny 1931/32, 1933, p. 140; M. Ambros, Stefan Vrtel-Wierczyński, p. 4; B. Kochańska, Stefan VrtelWierczyński (1886-1963). Bibliograf i bibliotekarz na łamach prasy, in: Rola ksiażki w integracji ziem polskich w XIX w., (ed.) B. Kosmanowa, Bydgoszcz 2000, p. 146.

43 Sprawozdanie $z$ działalności naukowo-dydaktycznej za rok akademicki 1933/34, in: Zespół akt prof. S. Wierczyńskiego. Archiwum Oddziału Polskiej Akademii Nauk w Poznaniu, sign. P. III - 32. Personal archive, entry no. 11; 'Wydział Humanistyczny', Kronika Uniwersytetu Poznańskiego za rok szkolny 1933/34, 1935, p. 170.

44 J. Maciejewski, Dzieje poznańskiej polonistyki, p. 48. 
elaborated, ${ }^{45}$ a year later, the contents of Pamiętnik Warszawski [The Warsaw Diary] from $1815,{ }^{46}$ and in the 1934/1935 and 1935/1936 academic years, the same journal published between 1815 and $1823 .{ }^{47}$ Thus, the researcher paid special attention to bibliographic practice so that students could acquire skills in using and creating information tools. This is also evidenced by the fact that although the history and literary seminar had its own library, ${ }^{48}$ the classes were held in the building of the University Library, which was treated as a workshop for bibliographic work.

As part of the classes, speeches and polemical speeches were also prepared. For example, in the 1934/1935 academic year, 26 speeches and polemical speeches were developed on the theory of bibliography and the methodology of literary research, the history of printing and the history of Polish libraries. ${ }^{49}$

It is worth paying attention to the organisation of bibliographic subjects. In the 1928/1929 academic year, classes were conducted in the first and second trimesters, in all three trimesters in the 1929/1930-1934/1935 academic years, and in the second and third trimesters in the last two years, (from one to two hours each week). From 12-16 (1929/1930) to 50 students (1932/1933) participated in these lectures and exercises. ${ }^{50}$

The second block of subjects introduced to the university by VrtelWierczyński included classes on the science of books: in the 1935/1936 academic year, under the name Bibliology and bibliography (one-hour classes in the first trimester with the annotation 'tasks and methods of research with practical

45 Sprawozdanie z działalności naukowo-dydaktycznej za rok akademicki 1934/35, in: Zespót akt prof. S. Wierczyńskiego. Archiwum Oddziału Polskiej Akademii Nauk w Poznaniu, sign. P. III - 32. Personal archive, entry no. 11. The same: 'Wydział Humanistyczny', Kronika Uniwersytetu Poznańskiego za rok szkolny 1934/35, 1936, pp. 165-166, 174-175.

46 Filologia nowożytna i historia nowszych literatur, in: Skład Uniwersytetu i spis wykładów na rok akademicki 1935/36. Poznań 1935, pp. 132-133.

47 Ćwiczenia bibliograficzne, pp. 147-148.

48 Wydział Filozoficzny, pp. 526-529.

49 Sprawozdanie $z$ działalności naukowo-dydaktycznej za rok akademicki 1934/35, entry no. 11; 'Wydział Humanistyczny', Kronika Uniwersytetu Poznańskiego za rok szkolny 1934/35, 1936, pp. 165-166, 174-175.

50 Filologia nowożytna i historia nowszych literatur, in: Spis wykładów i skład Uniwersytetu na rok akademicki 1932/33, Poznań 1932, p. 51. 
exercises') and a year later as Bibliology (also in one-hour classes in the first trimester). During the course, the lecturer discussed the issues of the theory and history of the discipline (the history and development of writing and books) and presented the impact of the invention of printing on the development of the science. ${ }^{51}$ Probably at least some of the content presented came from his habilitation publication entitled Bibliografia. Jej istota, przedmiot i poczattki [Bibliography: Its Essence, Subject and Origins] (Lviv 1923). ${ }^{52}$

From the 1930/1931 academic year, Vrtel-Wierczyński included librarianship in the university didactics programme. In the first year, he began to run classes called An outline of the history of libraries in Poland (one hour each week in the first trimester)..$^{53}$ The scope covered the common history of libraries and the history of libraries in the Commonwealth (particularly university libraries). ${ }^{54}$ The subject of librarianship was continued in the following years, but not in the form of a historical discourse. The scholar discussed the practical problems of librarianship with students, such as the types of libraries, the organisation and management of libraries, library law and techniques for using library collections. He also taught methods of cataloguing and inventorying collections (including manuscripts). ${ }^{55}$ These classes were held between the 1931/1932 and 1936/1937 academic years under the following names:

51 M. Błochowiak, Działalność pedagogiczna i edytorska, pp. 75-76.

52 The first part of the book is devoted to the subject, scope and concept of bibliology and bibliography (the birth of the theory of the science of books in Europe, the development of the discipline as an academic science in the territory of the Republic of Poland, the spread of new knowledge); the second part includes the content of the history of bibliographic registers - from antiquity (primarily in Greece and Rome), through the Middle Ages, including the history of censuses in Poland, to the appreciation of the role of the invention of movable type in the development of both bibliography and other bibliological subdisciplines (printing, bookselling).

53 Filologia nowożytna i historia nowszych literatur, in: Spis wykładów na 1, 2, 3 trymestr roku akademickiego 1930/31, Poznań 1930, p. 64.

54 M. Błochowiak, Działalność pedagogiczna i edytorska, pp. 75-76.

55 Sprawozdanie $z$ działalności naukowo-dydaktycznej za rok akademicki 1935/36, in: Zespół akt prof. S. Wierczyńskiego. Archiwum Oddziału Polskiej Akademii Nauk w Poznaniu, sign. P. III - 32. Archiwum osobiste, poz. spisu 11. Cf. The same: 'Wydział Humanistyczny', Kronika Uniwersytetu Poznańskiego za rok szkolny 1935/36, 1937, pp. 147-148; M. Błochowiak, Działalność pedagogiczna i edytorska, pp. 75-76. 
The main principles of librarianship (1931/1932, 1933/1934 and 1935/1936), An outline of librarianship (1932/1933), An outline of library science (1934/1935) and Principles of librarianship (1936/1937). They were conducted for one hour each week in the second or third trimesters. ${ }^{56}$

The block of philological classes included, in turn, the issues of PolishCzech literary relations and Polish medieval literature. The first subject that appeared in the 1928/1929 academic year was Polish-Czech literary relations, ${ }^{57}$ which was the result of Vrtel-Wierczyński's research interests. Before he started his lectures, he had published Rozmowa człowieka ze śmierciq $w$ literaturze średniowiecznej polskiej i czeskiej [The Conversation of Man with Death in Polish and Czech Medieval Literature] (Lviv 1926), Adam Junosza Rościszewski „przedstawiciel potomności” Zakładu Narodowego im. Ossolińskich $i$ jego korespondencja $z$ Wacławem Hanka [Adam Junosza Rościszewski, a 'Representative of Posterity' of the Ossoliński National Institute and His Correspondence with Wacław Hanka] (Poznań 1928) and Staroczeski dialog moralizujący z początku wieku XVI-go Rozmlouván člověka se Smrtí [The Old Bohemian Moralising Dialogue from the Early16th Century Rozmlouván člověka se Smrtí] (Prague 1928).

In the following years, he regularly conducted literary classes under the names: From the history of medieval Polish literature (1929/1930), Reading and explaining Polish medieval texts (1932/1933), Reading Polish medieval texts (1933/1934), From the history of Polish medieval literature (Legends) (1934/1935), Introduction to the study of Polish medieval literature (1935/1936), Polish medieval literature (a historical outline) (1936/1937) and Polish literature in the late Middle Ages and early Renaissance (1930/1931 and 1931/1932). For students, he also prepared an aid entitled Wybór tekstów staropolskich.

56 Filologia nowożytna i historia nowszych literatur, in: Spis wykładów na 1, 2, 3 trymestr roku akademickiego 1931/32, Poznań 1931, p. 66; Wydział Humanistyczny, Kronika Uniwersytetu Poznańskiego za rok szkolny 1932/33, 1934, pp. 125-126; Filologia nowożytna i historia nowszych literatur, in: Spis wykładów i skład Uniwersytetu na rok akademicki 1932/33, Poznań 1932, p. 52; Filologia nowożytna i historia nowszych literatur, in: Spis wykładów i skład Uniwersytetu na rok akademicki 1933/34, Poznań 1933, pp. 51-52.

57 Filologia nowożytna i historia nowszych literatur, in: Spis wykładów na 1, 2, 3 trymestr roku akademickiego 1928/29, Poznań 1928, pp. 58-60. 
Czasy najdawniejsze do r. 1543 [A Selection of Old Polish Texts: The Most Ancient times until 1543] (Lviv 1930). Philology classes were held in each of the three trimesters, one hour per week. ${ }^{58}$

The aforementioned cooperation with Pollak also resulted in VrtelWierczyński running a literary seminar. These classes were certainly held between 1934/1935 and 1936/1937..$^{59}$ From the personal documents of the bibliologist, kept in the Archives of the Polish Academy of Sciences Branch in Poznań, we learn that in the 1934/1935 academic year, second-year students participated in the seminar (on average, 28 people attended). It was divided into two groups that today can be called specialisations: literary and historical-cultural. In these classes, Vrtel-Wierczyński included the issues of the history of Polish magazines from 1795 to 1863 (along with a display of periodicals), and among others, characterised literary trends, the history of literary motifs and the state of research on Ignacy Krasicki's output. As a result, 12 speeches and polemical speeches were created ${ }^{60}$ In the following year, at 24 seminar meetings, first-year students delivered 27 speeches and co-speeches (on literary monuments of the Middle Ages, important themes from the literature of the 16th-17th centuries, the history of Polish culture, and the theory and methodology of literary research). The content of these meetings was also

58 Filologia nowożytna i historia nowszych literatur, in: Spis wykładów na 1, 2, 3 trymestr roku akademickiego 1929/30, Poznań 1929, p. 59; Filologia nowożytna i historia nowszych literatur, in: Spis wykładów na 1, 2, 3 trymestr roku akademickiego 1931/32, Poznań 1931, p. 66; 'Wydział Humanistyczny', Kronika Uniwersytetu Poznańskiego za rok szkolny 1932/33, 1934, pp. 125-126; Filologia nowożytna i historia nowszych literatur, w: Spis wykładów i skład Uniwersytetu na rok akademicki 1932/33, Poznań 1932, p. 52; Filologia nowożytna i historia nowszych literatur, in: Spis wykładów i skład Uniwersytetu na rok akademicki 1933/34, Poznań 1933, pp. 51-52; Filologia nowożytna $i$ historia nowszych literatur, in: Skład Uniwersytetu i spis wykładów na rok akademicki 1934/35, Poznań 1934, p. 128.

59 Spis wykładów na rok 1936/37, in: Zespół akt prof. S. Wierczyńskiego. Archiwum Oddziału Polskiej Akademii Nauk w Poznaniu, sign. P. III - 32. Personal archive, entry no. 11; Filologia nowożytna i historia nowszych literatur, in: Skład Uniwersytetu i spis wykładów na rok akademicki 1936/37, Poznań 1936, p. 137.

60 Sprawozdanie z działalności naukowo-dydaktycznej za rok akademicki 1934/35, entry no. 11. The same: 'Wydział Humanistyczny', Kronika Uniwersytetu Poznańskiego za rok szkolny 1934/35, 1936, pp. 165-166, 174-175. 
filled with exercises in the areas of reading Polish medieval texts, text criticism and publishing methodology. ${ }^{61}$

After Vrtel-Wierczyński moved to Warsaw in 1937, the classes ceased to take place, but the bibliologist was still mentioned in the lists of lectures delivered at the University of Poznan in the 1937/1938 and 1938/1939 academic years and in the staff lists. According to The List of Lectures Delivered in the 1937/38 Academic Year, the scholar was to conduct the most extensive series of classes, namely: Polish medieval literature (an outline of history), An outline of the history of books in antiquity and the Middle Ages to the invention of the art of printing, A literary seminar for first-year students, Bibliography, theory and methodology, Polish libraries (an outline of the history and their present state), Polish and foreign bibliography (an outline of the history and a review of sources) and Librarianship. ${ }^{62}$ A year later, he was to start teaching Bibliography and Bibliology ${ }^{63}$ Today it is difficult to assess whether the classes actually took place, but Vrtel-Wierczyński himself, in his own curriculum vitae, admitted that he finished working at the university in the 1936/1937 academic year. ${ }^{64}$

\section{Conclusions}

Summing up Vrtel-Wierczyński's achievements at the University of Poznań, it is necessary to emphasise the wide range of issues addressed during his classes. One cannot ignore his constant efforts to establish departments of auxiliary sciences and bibliology/bibliography in state universities, which would sanction the developing science of books in a new form. Arguing

61 Filologia nowożytna i historia nowszych literatur, in: Skład Uniwersytetu i spis wykładów na rok akademicki 1935/36, Poznań 1935, pp. 132-133.

62 Filologia nowożytna i historia nowszych literatur, in: Spis wykładów na rok akademicki 1937/38, Poznań 1937, pp. 67-68.

63 Filologia nowożytna i historia nowszych literatur, in: Spis wykładów na rok akademicki 1938/39, Poznań 1938, p. 69.

64 [S. Vrtel-Wierczyński], Życiorys, in: Zespół akt prof. S. Wierczyńskiego. Archiwum Oddziału Polskiej Akademii Nauk w Poznaniu, sign. P. III - 32, entry no. 129-140, p. [8] (He probably mistakenly entered 1923 as the year in which he started his lectures because he started working in Poznań in 1927); [S. Wierczyński], Wykłady księgoznawstwa w Uniwersytecie Poznańskim, p. 70. 
for the need to establish a bibliography and bibliology programme within the humanities, the researcher wrote:

We know... how important the role of these sciences is in the world of books, in science and in the practice of life. They are a guide to the vast labyrinth of science and enable the good organisation, control and exchange of the printed output of all peoples and times. ${ }^{65}$

The development of each of the sciences, primarily the sciences using the historical method, was therefore to be based on the achievements of this auxiliary specialisation, which was also an element of 'correct research methodology'. The theoretician did not see any substantive obstacles to making these sciences academic subjects 'in themselves', which he proved with his classes. Establishing the department of the science of books at the university could also help academic young people, with a passion for scientific research, in the proper construction of work techniques. The classes, which Vrtel-Wierczyński included in the didactic cycle of the Faculty of Humanities, allowed students to learn the rules of using bibliographic aids, to become familiar with the history of books and print, the theory of bibliography and the history of libraries, which were useful during classes in the field of the history of literatureand also - as the scholar himself admitted - in a 'teacher's life'. Thus, the content of his subjects covered a number of 'issues containing valuable general cultural values. ${ }^{66}$ The series of meetings devoted to the earliest history of Polish literature and elements of book culture supported young adepts of research in the humanities field.

\section{Literature}

Ambros M., 'Stefan Vrtel-Wierczyński jako bibliograf', Przegląd Biblioteczny, 1-2 (1964) pp. 3-10.

Baumgart J., 'Działalność Edwarda Kuntzego na stanowisku dyrektora Biblioteki Uniwersyteckiej w Poznaniu (1919-1926)', Przegląd Biblioteczny, 2/3 (1957) pp. 106-111.

Baumgart J., 'Działalność prof. Stefana Vrtela-Wierczyńskiego w zakresie bibliografii', Roczniki Biblioteczne, 1-2 (1984) pp. 41-57.

65 Referat o działalności naukowej Doc. Dra Stefana Wierczyńskiego, entry no. 139. 66 W sprawie studium bibliografii i bibliologii, entry no. 139. 
'Biblioteka Uniwersytecka. Sprawozdanie dyrektora Biblioteki Uniwersyteckiej prof. dra S. Wierczyńskiego za rok akademicki 1936/37', Kronika Uniwersytetu Poznańskiego za rok szkolny 1936/37, 1938, pp. 79-81.

Biernacka M. M., Wykłady Karola Estreichera w Szkole Głównej w Warszawie 1865-1868. Studium bibliologiczne, Warszawa 1989.

Błochowiak M., 'Działalność pedagogiczna i edytorska prof. Stefana Vrtela-Wierczyńskiego', Roczniki Biblioteczne, 1-2 (1984) pp. 75-89.

Bykowski L., 'Biblioteczna praca informacyjna w Polsce', Wiedza i Życie, 5 (1934) pp. 435-437.

Ciechanowska Z., 'Jerzy Samuel Bandtkie jako bibliotekarz i bibliotekoznawca', Biuletyn Biblioteki Jagiellońskiej, 1-2 (1970) pp. 5-23.

'Ćwiczenia bibliograficzne', Kronika Uniwersytetu Poznańskiego za rok szkolny 1935/36, 1937, pp. 147-148.

Filologia nowożytna i historia nowszych literatur, in: Skład Uniwersytetu i spis wykładów na rok akademicki 1934/35, Poznań 1934, pp. 126-130.

Filologia nowożytna i historia nowszych literatur, in: Skład Uniwersytetu i spis wykładów na rok akademicki 1935/36. Poznań 1935, pp. 130-135.

Filologia nowożytna i historia nowszych literatur, in: Skład Uniwersytetu i spis wykładów na rok akademicki 1936/37, Poznań 1936, pp. 135-139.

Filologia nowożytna i historia nowszych literatur, in: Spis wykładów i skład Uniwersytetu na rok akademicki 1932/33, Poznań 1932, pp. 49-54.

Filologia nowożytna i historia nowszych literatur, in: Spis wykładów i skład Uniwersytetu na rok akademicki 1933/34, Poznań 1933, pp. 50-53.

Filologia nowożytna i historia nowszych literatur, in: Spis wykładów na 1, 2, 3 trymestr roku akademickiego 1928/29, Poznań 1928, pp. 57-62.

Filologia nowożytna i historia nowszych literatur, in: Spis wykładów na 1, 2, 3 trymestr roku akademickiego 1929/30, Poznań 1929, pp. 56-62.

Filologia nowożytna i historia nowszych literatur, in: Spis wykładów na 1, 2, 3 trymestr roku akademickiego 1930/31, Poznań 1930, pp. 61-67.

Filologia nowożytna i historia nowszych literatur, in: Spis wykładów na 1, 2, 3 trymestr roku akademickiego 1931/32, Poznań 1931, pp. 63-69.

Filologia nowożytna i historia nowszych literatur, in: Spis wykładów na rok akademicki 1937/38, Poznań 1937, pp. 65-70.

Filologia nowożytna i historia nowszych literatur, in: Spis wykładów na rok akademicki 1938/39, Poznań 1938, pp. 68-72.

Gołda A., Teoria bibliografii w II Rzeczypospolitej, Katowice 2018.

Góra B., „Poznańczycy”: Edward Kuntze, Stefan Vrtel-Wierczyński, Aleksander Birkenmajer i ich reformatorska polityka biblioteczna, in: Oblicza współczesnej bibliologii. Konteksty i transgresje, (eds) G. Czapnik, Z. Gruszka, J. Ladorucki, Łódź - Warszawa 2014, pp. 415-444. 
Jastrzębski J., 'Reforma szkolnictwa akademickiego z 1933 roku. Zmiany w organizacji uczelni', Wschodni Rocznik Humanistyczny, 7 (2010-2011) pp. 255-272.

Kłossowska M., 'Aleksander Wiktor Bohatkiewicz. (Pierwszy wileński teoretyk i wykładowca bibliografii)', Studia o Książce, 2 (1971) pp. 221-239.

Kobelska A., Miasto. Uniwersytet. Literaturoznawstwo. Poznań lat dwudziestych i trzydziestych XX wieku jako przestrzeń działania członków Koła Polonistów, Warszawa 2016.

Kochańska B., Stefan Vrtel-Wierczyński (1886-1963). Bibliografi i bibliotekarz na łamach prasy, in: Rola książki w integracji ziem polskich w XIX w., (ed.)) B. Kosmanowa, Bydgoszcz 2000, pp. 145-156.

Koller J., 'Nowy dyrektor Biblioteki Narodowej w Warszawie', Monitor Polski, 149 (1937) p. 9.

Zespół akt prof. S. Wierczyńskiego. Archiwum Oddziału Polskiej Akademii Nauk w Poznaniu, sign. P. III - 32.

Korpała J., Dzieje bibliografii w Polsce, Warszawa 1969.

'Kurs bibliotekarski w Poznaniu', Bibliotekarz, 5/6 (1919) pp. 78-79.

'Kurs dla kandydatów na bibliotekarzy o średnim wykształceniu dla bibliotek naukowych w Bibliotece Uniwersyteckiej w Poznaniu', Exlibris, 3 (1920) pp. 80-82.

Lewicki K., 'Jerzy Samuel Bandtkie profesor bibliografii Uniwersytetu Jagiellońskiego 1811-1835', Roczniki Biblioteczne, 1-2 (1972) pp. 113-138.

Łodyński M., 'Rola Edwarda Kuntzego w bibliotekarstwie polskim', Przegląd Biblioteczny, 2-3 (1957), pp. 97-105.

Łukomski G., Jak powstał Uniwersytet Poznański, in: W Trzemesznie i nie tylko... Obchody 85-lecia Uniwersytetu im. Adama Mickiewicza, red. B. Walczak, Poznań 2006.

Maciejewski J., Dzieje poznańskiej polonistyki uniwersyteckiej 1842-1988, Poznań 1992.

Nowodworski W., „Bibliograficznych ksiag dwoje” Joachima Lelewela. Studium historyczno-bibliograficzne na tle epoki, Wrocław 1959.

Puciatowa A., 'Wspomnienie o dyrektorze Biblioteki Narodowej Stefanie Wierczyńskim', Rocznik Biblioteki Narodowej, 17-18 (1981-1982) pp. 423-439.

[Inc.: Rok akademicki 1928/29], Kronika Uniwersytetu Poznańskiego za rok szkolny 1927/28, 1928, pp. 3-20.

(s.b.), 'Podział Wydziału filozoficznego Uniwersytetu Poznańskiego', Kurier Poznański, 313 (evening edition) (1925) p. 7.

'Sprawozdanie dziekana Wydziału Humanistycznego prof. K. Chodynickiego za r. ak. 1933/34', Kronika Uniwersytetu Poznańskiego za rok szkolny 1933/34, 1935, pp. 66-80.

Starnawski J., Ludzie książki. Seria II, Łódź 2008.

Szkutnik Z., 'Stefan Vrtel-Wierczyński jako bibliotekarz', Roczniki Biblioteczne, 1-2 (1984) pp. 15-39.

Świderski B., 'Stefan Vrtel-Wierczyński 1886-1963', Roczniki Biblioteczne, 1-2 (1963) pp. 1-31.

Tokarzówna K., 'Stefan Vrtel-Wierczyński (26 grudnia 1886 - 3 lutego 1963)', Pamiętnik Literacki, 4 (1963) pp. 557-564. 
Treichel I., 'Pierwszy polski podręcznik bibliotekarski', Roczniki Biblioteczne, 1-2 (1957) pp. 167-230.

Vrtel-Wierczyński S., Biblioteka Uniwersytecka 1919-1929, in: Biblioteki wielkopolskie i pomorskie, (ed.) S. Wierczyński, Poznań 1929, pp. 91-116.

Warda K., 'Paweł Jarkowski - bibliotekarz i bibliograf', Kieleckie Studia Bibliologiczne, 2 (1995) pp. 9-29.

[Wierczyński S.], 'Wykłady księgoznawstwa w Uniwersytecie Poznańskim', Biuletyn Biblioteki Publicznej m.st. Warszawy, 10-11 (1932/1933) p. 70.

Więckowska H., Akademickie kształcenie bibliotekarzy. Zarys historyczny, Warszawa 1979.

Włodarczyk J., 'Bibliotekarze bibliotek fundacyjnych i rodowych w okresie zaborów próba syntezy. Z dziejów kształtowania się zawodu bibliotekarskiego na ziemiach polskich', Roczniki Biblioteczne, 1-2 (1984) pp. 179-195.

Wydział Filozoficzny, in: Uniwersytet Poznański w pierwszych latach swego istnienia (1919, 1919-20, 1920-21, 1921-22, 1922-23) za rektoratu Heliodora Święcickiego. Księga pamiątkowa wydana staraniem Senatu Uniwersytetu Poznańskiego, (ed.) A. Wrzosek, Poznań 1924, pp. 355-509.

'Wydział Humanistyczny', Kronika Uniwersytetu Poznańskiego za lata szkolne 1929/30 i 1930/31, 1932, pp. 67-80.

'Wydział Humanistyczny', Kronika Uniwersytetu Poznańskiego za rok szkolny 1927/28, 1928, pp. 48-59.

'Wydział Humanistyczny', Kronika Uniwersytetu Poznańskiego za rok szkolny 1931/32, 1933, pp. 130-142.

'Wydział Humanistyczny', Kronika Uniwersytetu Poznańskiego za rok szkolny 1932/33, 1934, pp. 112-128.

'Wydział Humanistyczny', Kronika Uniwersytetu Poznańskiego za rok szkolny 1933/34, 1935, pp. 148-170.

'Wydział Humanistyczny', Kronika Uniwersytetu Poznańskiego za rok szkolny 1934/35, 1936, pp. 121-196.

'Wydział Humanistyczny', Kronika Uniwersytetu Poznańskiego za rok szkolny 1935/36, 1937, pp. 99-168.

Wydział Humanistyczny, in: Skład Uniwersytetu i spis wykładów na rok akademicki 1936/37, Poznań 1936, s. 24-28.

'Z Uniwersytetu Poznańskiego', Dziennik Poznański, 148 (1920) p. 2. 